\title{
MODELLING THE IMPACT OF WIND FARMS ON HOUSE PRICES IN THE UK
}

\author{
Sally SIMS ${ }^{1}$, Peter DENT ${ }^{2}$ and G. Reza OSKROCHI ${ }^{3}$ \\ 1 Department of Real Estate and Construction, School of the Built Environment, \\ Oxford Brookes University, Headington, Oxford, UK \\ Tel: +44 (0) 1865483459; Fax: +44 (0) 1865 383927; E-mail: ssims@brookes.ac.uk \\ 2 Department of Real Estate and Construction, School of the Built Environment, \\ Oxford Brookes University, Headington, Oxford, UK \\ E-mail:prdent@brookes.ac.uk \\ ${ }^{3}$ Department of Mathematical Sciences, School of Technology, Oxford Brookes University, \\ Wheatley, Oxford, UK \\ E-mail: roskrochi@brookes.ac.uk
}

Received 28 January 2008; accepted 12 August 2008

\begin{abstract}
This paper discusses the findings from a UK study to determine the likely impact of a wind farm on house prices using a hedonic pricing model. The Government's commitment to wind power has resulted in a massive increase in the number of wind farms sited in the UK. This has led to concerns that their visual and aural presence could have a negative impact on proximate house prices. This paper presents an analysis of 201sales transactions from houses situated within half a mile of a 16 turbine wind farm in Cornwall, UK. Whilst no causal link was established between the presence of the wind farm and house price, there was some evidence to suggest that both noise and flicker from the turbine blades could blight certain property and that the view of countryside enjoyed by the occupier had some value which may be affected by a wind farm.
\end{abstract}

KEYWORDS: Property stigma; Residential values; Wind-power; Renewable energy; Hedonic

\section{INTRODUCTION}

The 2007 Energy White Paper, published in May 2007, sets out the Government's international and domestic energy strategy to respond to Climate Change with the main aim of cutting, "CO $\mathrm{CO}^{2}$ emissions [in the UK] by some $60 \%$ by about 2050, with real progress by 2020” (DTI, 2007). In order to meet these targets, the government expects " $20 \%$ of our energy to come from renewable sources...by 2020” (BBC Radio 4, 2007).

According to the Sustainable Development Commission (SDC, 2005), wind is a prime can- didate since the UK has the "best and most geographically diverse wind resources in Europe, more than enough to meet current renewable energy targets" (ibid). However, although wind power is now the fastest growing renewable energy sector in Britain (BBC Radio 4, 2007), "experts interviewed on 'Costing the Earth,' claim that the power of the wind to deliver electricity is being overestimated" (Country Guardian, 2007). They argue that although the Government has already invested, "half a billion pounds so far" wind power has "as yet...failed to deliver half of one per cent of our electricity needs" (ibid). 
Whilst appearing to offer many advantages, there is now considerable opposition to such developments particularly with regard to their inefficiency, with many turbines producing less than $25 \%$ of their predicted output. The unreliability of wind generated electricity means that customers must have the ability to switch over from wind power to an alternative source of electricity, (produced from either nuclear, oil or coal fired power stations). In real terms, this means that "even on the most optimistic assumptions, renewable sources of energy, such as wind power, will have only a 'minor impact' on reducing carbon dioxide emissions" (Keay, 2005). The governments reliance on wind power as the main source of renewable energy has raised public concern, not just about the ability of this technology to provide sufficient energy to meet the 2020 target, but also with regard to the impact that the visual (see Figure 1) and aural presence of turbines could have on wildlife, surrounding property values and the health of residents living close by, particularly since the number of wind turbines sited around the UK continues to grow (Country Guardian,
2007; Sagrillo, 2003; WWF-UK, 2001; RSPB, 2005; Milner, 2004; BWEA, 2008).

With the current number of operational onshore wind farms standing at 167 and a further 30 under construction, 123 with planning consent and a further 225 being considered (BWEA, 2008), opposition towards wind farms seems to be growing exponentially, which would suggest that the 'wind farm' may be the latest environmental feature to stigmatise residential property (Clark, 2004; Newton and Harwood, 2005).

Previous research in the UK has generally focussed on public and professional opinions towards proposed wind farm developments or the perceived impact of an existing wind farm on house prices (Impact Assessment Unit, 2003). There has only been one previous study to attempt to quantify the real impact on value and that proved inconclusive due to a lack of available data (Sims and Dent, 2007). Therefore, further research to establish their impact on house values and amenity would be of benefit to property professionals and the wind generation industry.

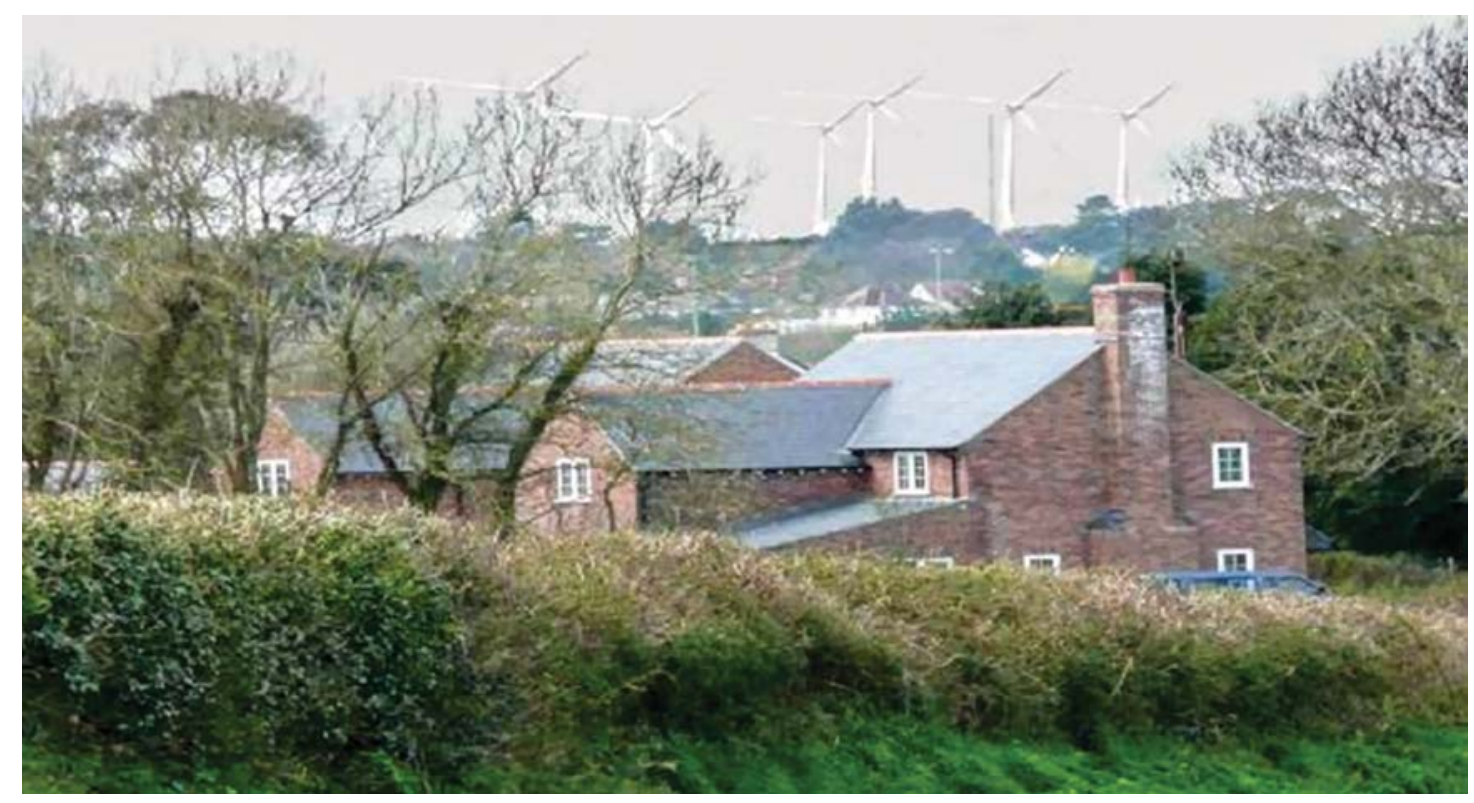

Figure 1. View of a wind farm from Nutcrack Lane, Dorset, UK 
This study seeks to establish whether, or not, the physical or visual presence of wind turbines influences house values or amenity by undertaking an analysis of property transactions. The report presents the results from an analysis of transaction data for homes sold in the vicinity of the Bears Down, 16 turbine wind farm in St Eval, Cornwall (turbines are $60 \mathrm{~m}$ high). A hedonic pricing model at the micro-spatial level is applied and data analysed using multiple linear regression.

\section{LITERATURE}

Whilst there have been several studies in this area, most have been opinion surveys. As a consequence there is little empirical evidence on the impacts (positive or negative) of living near a wind farm and only five studies which consider the impact on value. One study found a small number of homes could suffer from diminution (Jordal-Jorgensen, 1996). Two studies found insufficient evidence to either reject or accept the claim that wind farms have an effect on value (Poletti, 2005; Hoen, 2006). One found house values increased (Sterzinger et al., 2003) and the fifth, whilst finding a reduction in house values within one mile of the wind farm, attributed this diminution to a local condition and not the presence of the wind farm (Sims and Dent, 2007).

\subsection{Opinion surveys}

Public perception of non-physical contamination such as visual impacts, noise and odour pollution can create property stigma which, according to Chan (2001) is "a loss to property value due to the presence of a risk perception-driven market resistance." Previous research on the impact of environmental features such as, high voltage overhead power lines (HVOTLs) and mobile phone masts (MPBS) (both of which exhibit similar characteristics to wind turbines), indicates that, physical characteristics such as visibility, size and location can influence property stigma; especially when there is an associated health risk. However, the effect of stigma damage is difficult to quantify because it is created by opinion and perceptions which can change in response to media attention (see for example information available on the internet $^{1}$ ), time and spatial proximity (McClelland et al., 1990; Chalmers and Roehr, 1993; Fischhoff, 1985; Mundy, 1992; Slovic et al., 1991; Gallimore and Jayne, 1999; Bell, 1999; Bond et al, 2003; Sims and Dent, 2005). Most wind farm studies have been undertaken as part of an impact assessment statement prior to construction (Impact Assessment Unit, 2003). Survey work undertaken by the Scottish Executive (2003) suggests that residents living near wind farms have experienced less impact than anticipated as shown in Figures 2 and 3.

Q What effect, if any, would you say the presence of the windfarm has had on your local area?

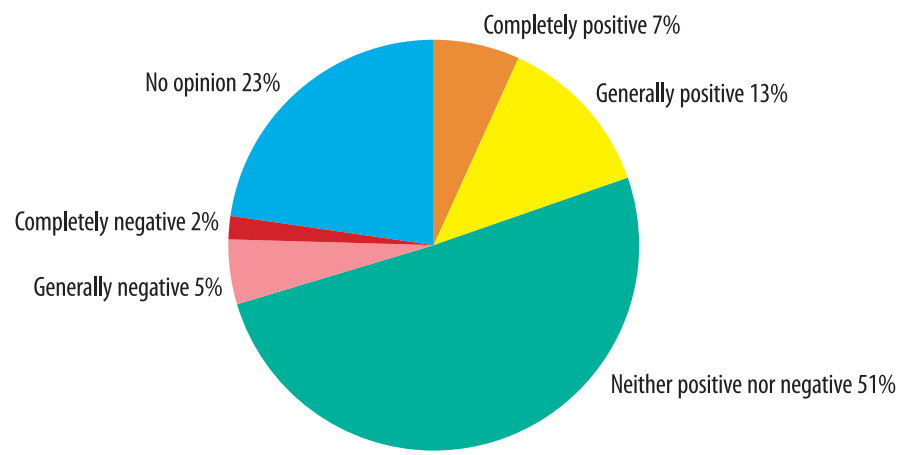

Base: Residents living within $20 \mathrm{~km}$ of a Scottish windfarm site (1.810) Source: MORI

Figure 2. Perceived impact of wind farms 


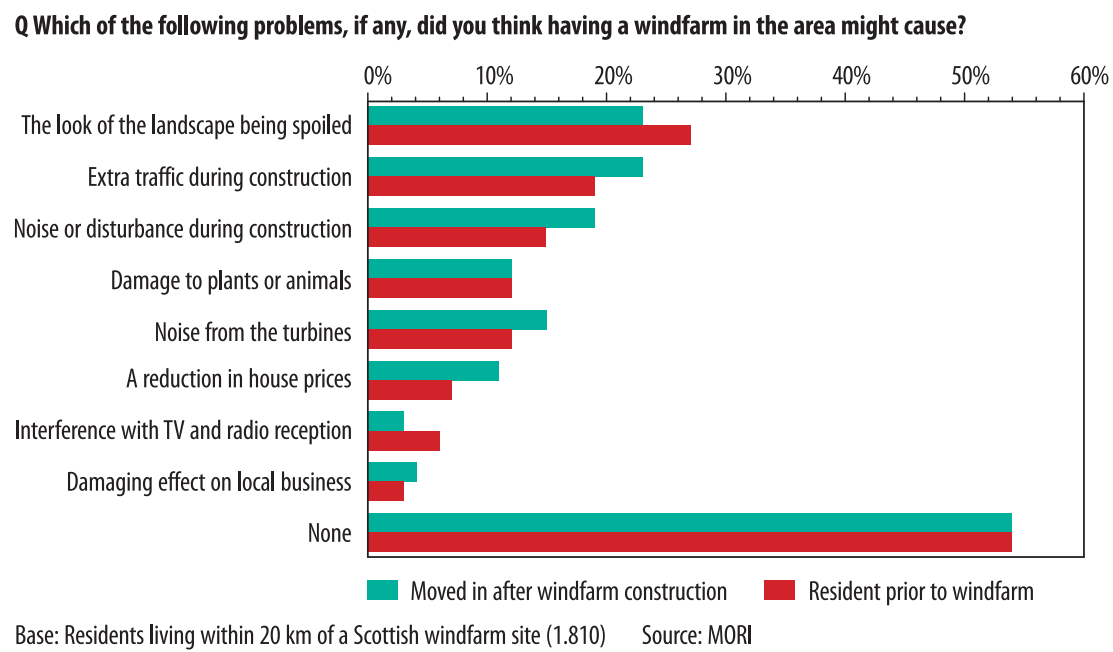

Figure 3. Perceived problems caused by wind farms

The British Wind Energy Association (BWEA, 2004) commissioned Knight Frank to undertake an initial investigation into the factors affecting property values near wind farms. The findings indicated that public reactions tend to vary considerably, with more support for wind farms being observed when the public are involved in the decision making process. However, although there was a general consensus amongst estate agents that there is a 'detrimental effect on values either due to close proximity of the wind farm or its visibility"(ibid), they concluded that determining the real impact on value would require a more detailed case study using data from the Land Registry and interviews with Property Professionals.

The 2004 Royal Institution of Chartered Surveyors (RICS, 2004) members' survey found that 60 per cent of the 405 respondents thought proximate wind farms decreased property values when the turbines were in view, despite a lack of evidence from sales transactions to support this view. The majority of respondents believed that any depreciation starts at the planning stage and lessens with time. Sims and Reed (2005) reached a similar conclusion when asking valuers to speculate on which features associated with a wind farm would be most likely to reduce value. The response (76 useable responses) indicated that a 'view of the turbine' would cause the largest diminution in value followed by a 'fear of blight'. The size of the wind farm seemed immaterial.

Other research has observed some positive benefits from wind farm development. Grover (2002) found that a plot of land with planning permission for a wind farm could be worth significantly more than land without (presumably due to the potential income stream). By contrast, Jordal-Jorgensen (1996) and Andersen and colleagues cited in Damborg (2002), explored the issue of co-ownership in Norway and Denmark and found that the most important factor to influence occupiers attitudes related to whether or not they benefited directly from the electricity produced (i.e. the degree of financial benefit to be derived from this technology). On the other hand, those owning or co-owning turbines expressed little or no objection to their presence.

\subsection{Valuation studies}

Jordal-Jorgensen (1996) was one of the first researchers to use a hedonic regression model to analyse the impact of a wind farm on house prices in Denmark. He attempted to quantify the visual and aural impact of wind turbines 
to enable the cost versus benefit of wind generated electricity to be calculated. Results indicated that, on average, eight homes are affected by a single turbine, six households by clusters and 12 by wind farms. Homes near a single turbine are on average Euro 2,174 cheaper than other houses in the vicinity and houses which lie closer to a wind farm containing 12 or more turbines are Euro 12,614 cheaper. However, not all were statistically significant and, therefore, impacts on house prices could be due to other factors.

Sterzinger et al. (2003) set out to determine whether the presence of a wind farm had any impact on proximate property values in the US. The study examined 24,300 property transactions from 10 locations within the US, over a period of six years; this period spanned, in some cases, three years prior to the siting of the wind farm and three years following installation. Using multiple regression to analyse data they concluded that there was little, or no evidence to suggest that wind farms sited within a five mile radius of property had a negative impact on value. In fact, to the contrary, property values appeared to rise above the regional average within the case study locations, suggesting that wind turbines actually had a positive effect on value. However the validity of Sterzinger's results are somewhat questionable (Hoen, 2006; Poletti, 2005) since, he included transactions which were not 'arms-length' (not undertaken under normal market conditions ie; divorce and sales between family members) and made "...the erroneous assumption that all properties within the 5-mile radii can see the wind farm, when many houses' views in fact are obstructed by geological features, trees and other houses" (Hoen, 2006).

Poletti's 2005 study of "roughly 300 sales" (Hoen, op cit) of homes around the Lincoln and Rosiere wind farms in Wisconsin and Illinois, found insufficient evidence to either confirm or reject the claim that wind farms have an effect on property values. Whilst the analysis was slightly more rigorous than Sterzinger; in that he that he removed any sales which were spurious (not arms-length transactions) he did not control for distance or factor in the degree of visual encumbrance each home experienced from the presence of the wind farm.

Hoen improved on earlier research by including variables which would measure the effect of distance and varying degrees of visual encumbrance on transaction price. He used a hedonic regression model to analyse 280 sales transactions from homes sold within five miles of a 20 turbine wind farm at Madison Country, New York and visited each home included in the sample to measure the degree to which the occupiers could see the turbines. He did not however, consider the orientation of the wind farm which had been found by Des Rosiers (2002) and Sims and Dent (2005) to have a significant impact on the degree of diminution suffered with regard to electricity pylons. He found no measurable effect from wind farm visibility on value, even where property was within one mile of a turbine.

Sims and Dent (2007) considered the 'before' and 'after' effects of wind farm development by first undertaking an analysis of nearly 900 transactions of homes sold between 20002005 within five miles of two wind farms in North Cornwall, UK, and then examining the likely reason for any diminution in value. Their analysis of Planning Application objections (obtained from Bodmin Planning Department) to the Bears Down wind farm ${ }^{2}$ in Cornwall indicated that, whilst many people objected to the wind farm at the planning stage, the majority of objections were received from members of the public who did not live in the area. This is partly explained by the fact that, in this particular area, nearly fifty per cent of dwellings were second homes. It is, therefore, difficult to measure the true reaction from permanent residents.

The second part of the study applied a hedonic regression model to analyse property sales. The results showed that, semi-detached 
and terraced houses situated within one mile of the wind farm were lower in price than a similar house situated at a distance of four or more miles from the nearest turbine, yet still in the same postal district. However, no linearity was observed between distance to the wind farm and value. Whilst the results suggest that the wind farm could be responsible for this diminution, selling agents attributed any reduction in value specifically to a local condition (the fact that the majority of houses within one mile of the wind farm were exMinistry of Defence (MOD) homes built for air force personnel stationed at St Eval Airbase). In addition, the large number of houses included in the sample (919, before the outliers were removed), meant that the view of the wind farm from each house had not been measured and the vista (views of the surrounding countryside, sea or rivers) had only been estimated using GIS software (Google Earth ${ }^{3}$ ).

So far, despite improvements in research methodology, the results from existing studies remain inconclusive. The central aim of this study therefore, is to improve on existing research and develop a hedonic model which will capture the significant determinants of price for houses sold in close proximity to a wind farm.

\section{METHODOLOGY}

Having developed the basic methodological framework in the previous study, this research focused on property within one mile of the Bears Down wind farm as this is possibly, currently the only location within the UK where there are a sufficient number of sales transactions within close proximity to a wind farm to facilitate this type of modelling.

\subsection{Hedonic modelling}

The transaction price for a house will reflect the value placed on the particular set of locational and physical attributes it possesses. However, each house sale takes place in terms of a single transaction and consequently the implicit price placed on each attribute (characteristic) is not observed. Rosen (1974) provided the basis for the hedonic pricing framework in which goods are broken down into their main characteristics thus allowing the influence of each attribute on the total price to be determined. This approach has become an accepted method of conducting a robust analysis of property valuation data where sufficient data are available. Hedonic modelling allows property prices to be explained "on the basis of their physical and neighbourhood-related characteristics" (Des Rosiers et al., 2000; Rossini et al., 2002; Kauko, 2003); providing such features can be expressed in numerical form, such as time or distance (Des Rosiers et al., 2003), noise, measured in decibels (Rossini et al., 2002), or visual encumbrance (Bond et al, 2003). This methodology is particularly useful when determining the impact on value from a contaminant or detrimental condition, as it enables the combination of property specific variables and external or condition specific variables for every unit under consideration to be analysed by establishing a model, determining the parameters and then evaluating the result using multiple regression analysis (Kauko, 2002). Each characteristic then becomes a function of price $(P)$ and can be expressed as:

$$
P_{i}=b_{0}+b_{1} X_{1 i}+b_{2} X_{2 i}+\ldots+b_{j} X_{j i}+e_{i},
$$

where the price $(P)$ of each house $(i)$ is a function of its characteristics $X_{i}$ and $b_{1}, b_{2} \ldots . . b_{j}$ are the regression coefficients corresponding to the property and locational variables $\left(X_{j}\right)$. There are always several factors that will affect the total price but cannot be measured, in other words, the margin of error represented in the equation as $e_{i}$ (Fleming and Nellis, 1994).

A key concern with hedonic estimation is the size of the sample. Fletcher et al. (2000) explains that if a sample is large, the coefficient or value given to each characteristic in 
the model may not be stable over the complete data set and differences between property characteristics or sub-locations may be hidden resulting in biased coefficients. This was not a concern with the data used for this research since only 201 transactions were obtained for analysis. However, there was a risk that such a small sample may produce unreliable estimates of the coefficients because some characteristics may only apply to a small number of properties (ibid). That said, the hedonic pricing model has been used in the past to examine the impact of aircraft noise and high voltage overhead power lines on house price (Priestley and Ignelzi, 1989; Bond and Hopkins 2000; Des Rosiers 2002; Rossini et al., 2002) and is therefore well suited to "dissect the issues revolving around windfarm acceptance" (Hoen, 2006).

\subsection{Case study location}

This study focuses on homes located in St Eval, Cornwall (see Figures 4, 5, 6). Homes are sited at distances ranging between half a mile and one mile from Bears Down wind farm; a 16 turbine wind farm which has been in operation since 2001. The height of each turbine from the base of the hub to the maximum tip height of the rotor is approximately 60 metres. $^{4}$ The estate is fairly unusual in that it is part of a decommissioned US air-force base where 326 houses had been built for air-force personnel. In the year 2000, the part of this estate consisting of small terrace and semi-detached homes became available for private purchase, resulting in 201 sales transactions (54 were repeat sales). Of these, 131 were semi-detached and 70 terrace houses. Both house types have a range of views from the property which include the wind farm, surrounding countryside, sea and other houses.

Whilst individual houses within the two sub-sets were very similar, a physical inspection of each house in our data set was not possible which meant that factors, such as a loft conversion, which would have affected sellingprice were not included.

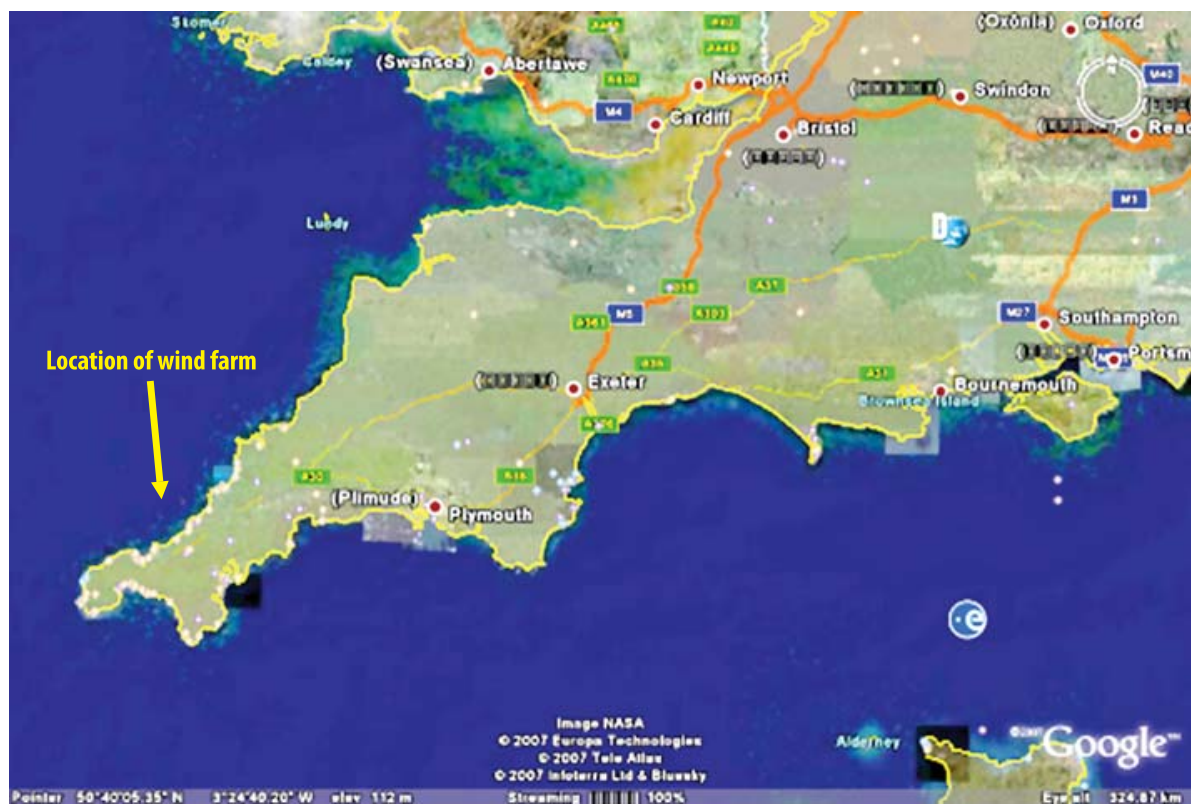

Reproduced with kind permission from Google

Figure 4. Location of Bears Down wind farm in North Cornwall 


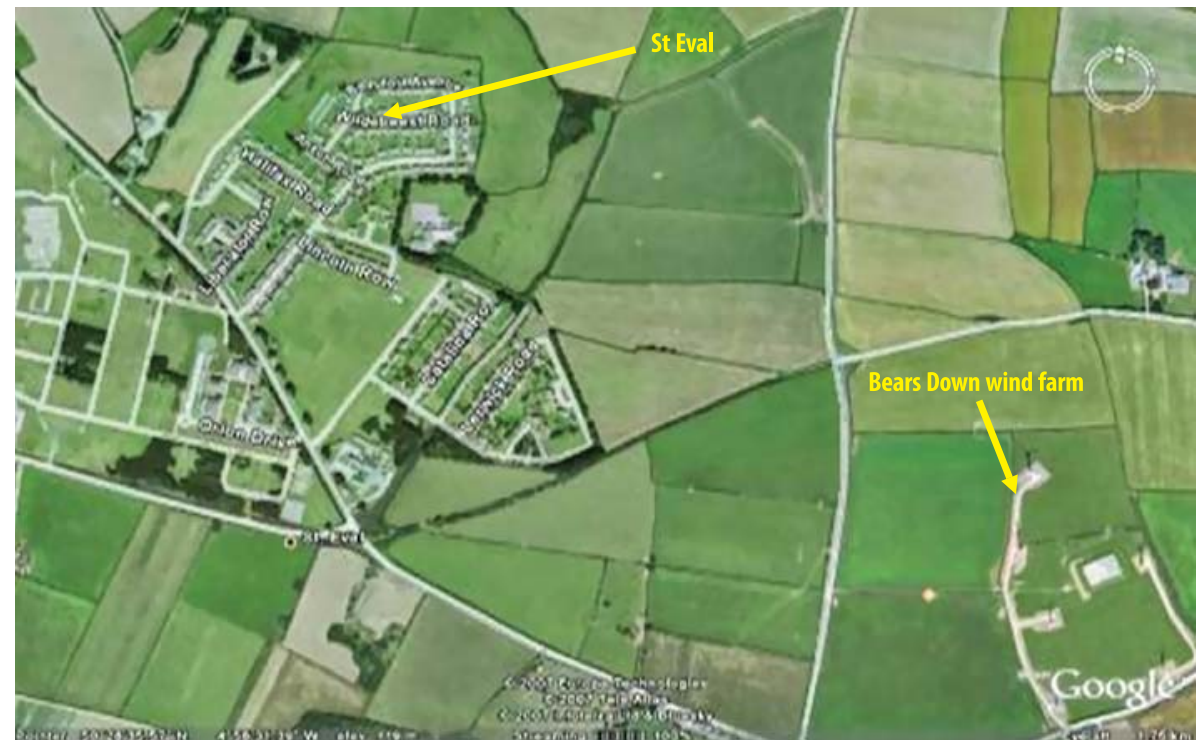

Reproduced with kind permission from Google

Figure 5. GIS view of the location of St Eval and Bears Down Windfarm

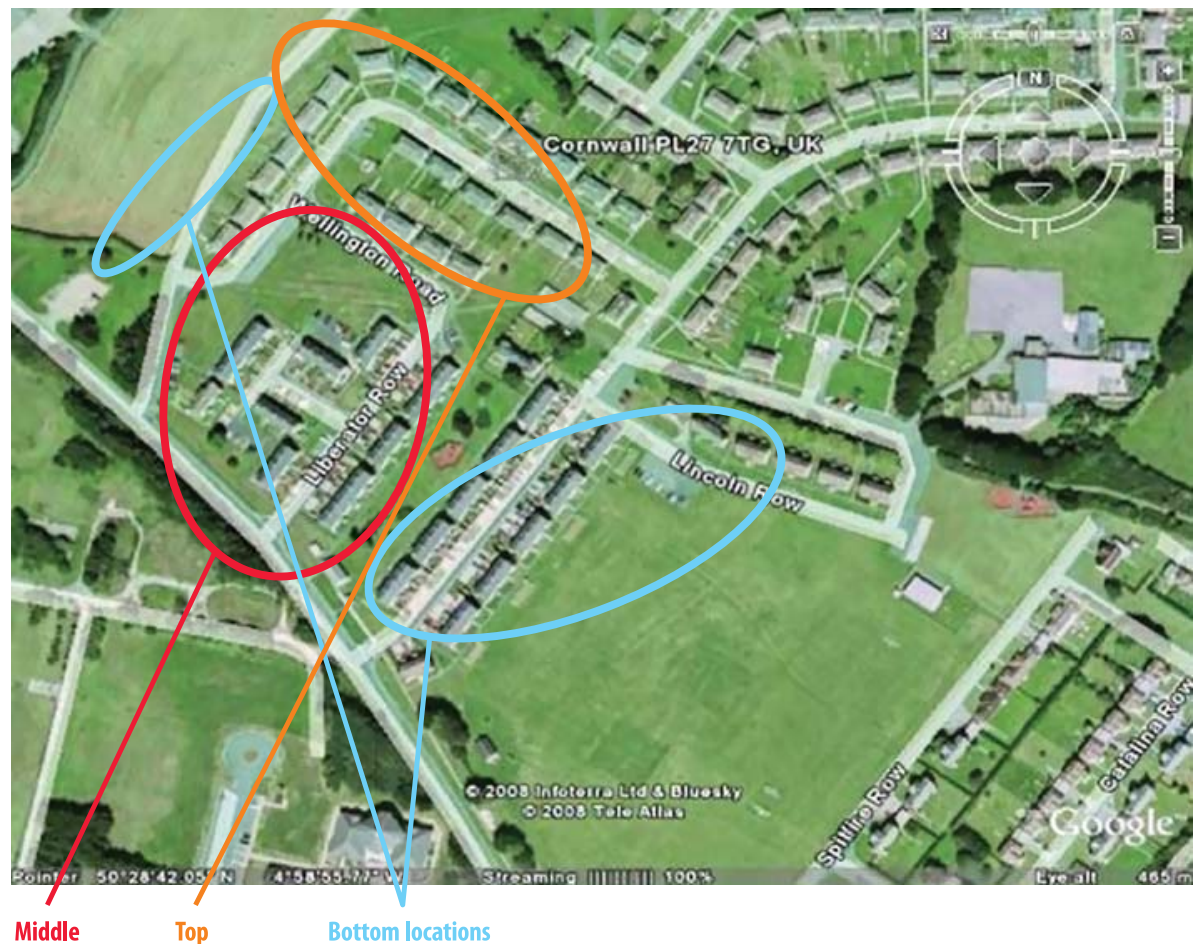

Reproduced with kind permission from Google

Figure 6. Aerial view of houses in St Eval showing the 3 locations in the sample (top, middle and bottom) according to price 


\subsection{Variable selection and data collection}

Transaction data for all house sales completed within the period 2000-2007 from the postcode area surrounding the Bears Down wind farm were gathered from Property POD online (www.propertypod.co.uk). Their online database provides details of all residential property sales in England and Wales, as recorded by the Land Registry since April 2000. This resulted in 201 property transactions and included in- formation on house type, date of sale and price. Addition data were gathered and divided into 3 categories (see Table 1 and 2). These were:

House Characteristics $=$ House type, number of bedrooms, parking facilities.

Locational View (Vista) $=$ Houses/other buildings, playing field, countryside, sea.

Wind farm Characteristics = Distance (DISTMETRE) from each house was measured using GIS. Site visits and GIS enabled the visual impact of the wind farm from the

Table 1. Variables used in the analysis

\begin{tabular}{lll}
\hline Variable name & Variable type & Explanation of the values \\
\hline Terrace & Dummy* & Type of property (Terrace house) \\
Semi & Dummy & Type of property (Semi-detached house) \\
No. of beds & Measurement & Number of bedrooms \\
PGARAGE & Dummy & Presence of a garage \\
P.Offroad & Dummy & Designated car parking available in driveway or off road \\
P.Onroad & Dummy & No designated parking space \\
Distmetre & Measurement & Distance to the nearest turbine in metres \\
FVista1 & Dummy & Vista from front of house $=$ Houses \\
FVista2 & Dummy & Vista from front of house $=$ Field \\
FVista3 & Dummy & Vista from front of house $=$ Countryside \\
RVista1 & Dummy & Vista from rear of house $=$ Houses \\
RVista2 & Dummy & Vista from rear of house $=$ Field \\
RVista3 & Dummy & Vista from rear of house $=$ Countryside \\
RVista4 & Dummy & Vista from rear of house $=$ Sea \\
FWF0 & Dummy & No view of windfarm from front of house \\
FWF1 & Dummy & Partial or full view of 1 turbine \\
FWF3 & Dummy & Partial or full view of up to 2 turbines from the front of house \\
FscreenV & Dummy & View of turbines screened at front of house \\
FsideV & Dummy & Side view of turbines from the front of house \\
FfacingV & Dummy & Facing view of turbines from the front of house \\
RWF0 & Dummy & No view of windfarm from the rear of house \\
RWF3 & Dummy & Partial or full view of up to 2 turbines from the rear of house \\
RSIDEV & Dummy & Side view of turbines from the rear of house \\
RFACINGV & Dummy & Facing view of turbines from the rear of the house \\
LNPRICE & Measurement & Natural log of adjusted price \\
NewH & Dummy & New build \\
Year sold & Dummy & Year of transaction \\
\hline
\end{tabular}

*A dummy variable is a numerical variable used in regression analysis to represent subgroups of the sample in this study. For instance, a terrace house would be given a value of 1 in the variable 'Terrace' and 0 in the variables 'Semi'. 
front and rear of the house to be calculated based on a scale of 0 to 4 , as shown below. 0 (FWF0 \& RWF0) = no view;

$1(\mathrm{FWF} 1 \& \mathrm{RWF} 1)=$ partial view of one turbine;

$2($ FWF2 \& RWF2) $=$ up to a complete view of one turbine and a partial view of another;

3 (FWF3 \& RWF3) = up to a complete view of 2 turbines and partial view of another.

$4(\mathrm{FWF} 4 \& \mathrm{RWF} 4)=$ a complete view of 3 or more turbines.

No house included in the analysis had a view of 3 or more turbines. The orientation of the wind turbines (from front and rear of house, see Table 1, 2 and 3) was also measured since the position of similar environmental features (HVOTLs) had been found to influence the degree of value diminution (Des Rosiers, 2002; Sims and Dent, 2005). Additional dummy variables were constructed to represent the year of sale and therefore analyse the effect of inflation more accurately, since the application of an inflation multiple was found to be inappropriate for this data.

Finally the issue of spatial autocorrelation was addressed since it is a fundamental concept in any geographically located data (e.g. house price) that nearby values often are more similar than values which are far apart. This concept is known as spatial dependency. In our data it reflects the positive co-variation of house prices within a geo-space (e.g. within a postcode). One explanation is that the transaction price in one location also affects the price of similar houses in nearby locations. Another explanation is spatial causality; some factor at a given location directly influences others in nearby locations.

Spatial dependency leads to a problem of spatial autocorrelation in statistics, since this violates standard statistical techniques that assume independence among observations. For example, in our data house prices within a postcode are not independent of each other, hence
Table 2. Descriptive statistics for dummy variables

\begin{tabular}{|c|c|c|c|}
\hline $\begin{array}{l}\text { Variable } \\
\text { name }\end{array}$ & $\mathrm{N}$ & $\begin{array}{l}\text { Mean } \\
(\% \text { Yes })\end{array}$ & $\begin{array}{l}\text { Std. } \\
\text { Deviation }\end{array}$ \\
\hline Terrace & 199 & .35 & .477 \\
\hline Semi & 199 & .65 & .477 \\
\hline Offroad & 199 & .50 & .501 \\
\hline Onroad & 199 & .50 & .501 \\
\hline FVista1 & 199 & .72 & .451 \\
\hline FVista2 & 199 & .27 & .446 \\
\hline FVista3 & 199 & .01 & .100 \\
\hline RVista1 & 199 & .83 & .377 \\
\hline RVista2 & 199 & .04 & .197 \\
\hline RVista3 & 199 & .04 & .185 \\
\hline RVista4 & 199 & .10 & .295 \\
\hline FWF0 & 199 & .77 & .423 \\
\hline FWF1 & 199 & .02 & .141 \\
\hline FWF3 & 199 & .21 & .409 \\
\hline FscreenV & 199 & .06 & .239 \\
\hline FsideV & 199 & .09 & .280 \\
\hline FfacingV & 199 & .09 & .280 \\
\hline RWF0 & 199 & .77 & .419 \\
\hline RWF3 & 199 & .23 & .419 \\
\hline RfacingV & 199 & .23 & .419 \\
\hline newH & 199 & .2915 & .45558 \\
\hline Bed3 & 199 & .4121 & .49345 \\
\hline year00 & 199 & .4221 & .49514 \\
\hline year01 & 199 & .0955 & .29461 \\
\hline year02 & 199 & .1256 & .33227 \\
\hline year03 & 199 & .0704 & .25638 \\
\hline year04 & 199 & .0603 & .23864 \\
\hline year05 & 199 & .1106 & .31437 \\
\hline year06 & 199 & .0854 & .28022 \\
\hline year07 & 199 & .0302 & .17143 \\
\hline Low-Location & 199 & .6432 & .48026 \\
\hline Med-Location & 199 & .2312 & .42264 \\
\hline Top-Location & 199 & .1256 & .33227 \\
\hline
\end{tabular}

regression analyses that do not control for spatial dependency can have unstable parameter estimates and yield unreliable significance tests. A special regression model is required to control this type of dependency (see for example Diggle and Ribeiro, 2007). Since the required GIS data are not available at individual 
Table 3. Frequency analysis of variables - relative to house type

\begin{tabular}{|c|c|c|}
\hline Variable & Terrace & Semi \\
\hline 2 bed & 65 & 53 \\
\hline 3 bed & 4 & 78 \\
\hline 4 bed & 0 & 1 \\
\hline Low-Location & 69 & 59 \\
\hline Med-Location & 0 & 46 \\
\hline Top-Location & 0 & 25 \\
\hline \multicolumn{3}{|l|}{ Vista from house } \\
\hline F Vista 1-houses & 55 & 90 \\
\hline F Vista 2 -field & 14 & 40 \\
\hline F Vista 3 -countryside & 0 & 2 \\
\hline F Vista 4 -sea & 0 & 0 \\
\hline $\mathrm{R}$ Vista 1 -houses & 66 & 101 \\
\hline R Vista 2 -field & 3 & 5 \\
\hline $\mathrm{R}$ Vista 3 -countryside & 0 & 7 \\
\hline $\mathrm{R}$ Vista 4 -sea & 0 & 19 \\
\hline \multicolumn{3}{|l|}{ Car Parking Spaces } \\
\hline off road & 37 & 65 \\
\hline on road & 32 & 67 \\
\hline \multicolumn{3}{|l|}{ View of wind farm from FRONT of house } \\
\hline No view of wind farm & 60 & 95 \\
\hline Partial or full view of 1 turbine & 0 & 4 \\
\hline Partial or full view of up to 2 turbines & 9 & 33 \\
\hline \multicolumn{3}{|c|}{ Orientation of wind farm from front of house } \\
\hline No View & 60 & 95 \\
\hline Screened View & 2 & 10 \\
\hline Side View & 0 & 17 \\
\hline Facing View & 7 & 10 \\
\hline \multicolumn{3}{|l|}{ View of wind farm from REAR of house } \\
\hline No view of wind farm & 57 & 99 \\
\hline Partial or full view of 1 turbine & 0 & 0 \\
\hline Partial or full view of up to 2 turbines & 12 & 33 \\
\hline \multicolumn{3}{|c|}{ Orientation of wind farm from rear of house } \\
\hline No View & 57 & 99 \\
\hline \multicolumn{3}{|l|}{ Screened View } \\
\hline Side View & 3 & 20 \\
\hline Facing View & 9 & 13 \\
\hline New build & 0 & 65 \\
\hline
\end{tabular}

house level, we are unable to apply regression methods for spatial data. Hence, for simplicity we take a parsimonious approach by applying a multiple linear regression which tries to reduce the effect of spatial dependencies by including a fixed effect intercept for homogenous postcodes (e.g. "toplocation", "Medlocation" with a reference category of "Lowlocation"). 


\section{ANALYSIS}

Data analysis was undertaken using SPSS. Frequency, and correlation tests were undertaken (see Tables 3 and 4) and the KolmogorovSmirnov test has been used to check the normality of the dependent variable (price). Tests for normality showed the data were not normal. This was probably due to two factors. First, the high number of properties sold in 2000 at the $£ 95,000-£ 99,000$ price range (84 sales); second, spatial autocorrelation. Natural log of price (LNPRICE) produced a slightly closer to normal curve $($ Mean $=11.17$, Std Dev. $=0.469)$, so this form was adopted for the regression analysis.

The first regression model used all variables, including time dummies, and applied to all 201 transactions. A complete residual analysis of the result suggested that two data points could be possible outliers. Careful consideration of these two transactions revealed that one of them sold as the most expensive house in its postcode $(£ 195,000)$ and the second one the least expensive transaction $(£ 46,000)$ for year (2003) in its postcode. It is anticipated that there could be a risk of measurement error on the time of transactions for these two houses and therefore it was decided to drop them from the analysis. It is important to mention that the significant result of the analysis was not af- fected by the elimination of these two outliers, but the residuals were closer to a normal curve without those two data points. All further analyses therefore applied to 199 transactions.

Table 5 shows the results for natural log of price (lnprice) as dependent variable and all other variables as independent variables. Obviously multicollinearity exists (VIF $>10$ ) between the dummy variable for $3 \& 4$ bedroom houses and dummies for the geographical location ("medlocation" and "toplocation"). By removing the least effective variable ("medlocation") all VIFs become less than 10 .

Table 6 shows the result of the regression model after controlling for multicollinearity and investigating interactions between significant variables. The coefficients, unsurprisingly, suggest that a terrace house is significantly less expensive than a semi-detached house. It was hypothesised that having a view of the countryside or sea would increase sale price, however this was not observed. Both screened and side views ("FscreenV" and "FsideV") of the wind farm from the front of the house positively contribute to transaction price. Conversely, a rear facing view of the wind farm ("RfacingV") significantly reduced transaction price. Note that "trsviewint" which is the interaction between terrace houses ("terrace") and a facing view of the wind farm from the rear of the house ("Rfac-

Table 4. Correlation coefficient

\begin{tabular}{llllll}
\hline Variable & & NoBed & DistMetre & $\begin{array}{l}\text { Time sold in months } \\
\text { from 1/1/2000 }\end{array}$ & lnprice \\
\hline NoBed & Pearson correlation & 1.000 & -.012 & $.349^{* *}$ & $.519^{* *}$ \\
& Sig. (2-tailed) & & .864 & .000 & .000 \\
DistMetre & Pearson correlation & -.012 & 1.000 & -.037 & -.086 \\
& Sig. (2-tailed) & .864 & & .605 & .229 \\
time sold in months & Pearson correlation & $.349^{* *}$ & -.037 & 1.000 & $.283^{* *}$ \\
from 1/1/2000 & Sig. (2-tailed) & .000 & .605 & & .000 \\
lnprice & Pearson correlation & $.519^{* *}$ & -.086 & $.283^{* *}$ & 1.000 \\
& Sig. (2-tailed) & .000 & .229 & .000 & \\
\hline
\end{tabular}

** Correlation is significant at the 0.01 level (2-tailed). 
Table 5. Regression Model - including all independent variables

\begin{tabular}{|c|c|c|c|c|c|c|}
\hline \multirow[t]{2}{*}{ Variables } & \multicolumn{2}{|c|}{$\begin{array}{l}\text { Unstandardized } \\
\text { coefficients }\end{array}$} & \multirow{2}{*}{$-\frac{\begin{array}{l}\text { Standardized } \\
\text { coefficients }\end{array}}{\text { Beta }}$} & \multirow[t]{2}{*}{ Sig. } & \multicolumn{2}{|c|}{$\begin{array}{l}\text { Collinearity } \\
\text { statistics }\end{array}$} \\
\hline & B & Std. Error & & & Tolerance & VIF \\
\hline & 10.585 & .254 & & .000 & & \\
\hline Terrace & -.063 & .015 & -.064 & .000 & .624 & 1.603 \\
\hline offroad & .011 & .020 & .012 & .585 & .318 & 3.143 \\
\hline FVista2 & .045 & .039 & .043 & .253 & .107 & 9.325 \\
\hline FVista 3 & -.132 & .075 & -.028 & .079 & .587 & 1.704 \\
\hline RVista2 & .069 & .051 & .029 & .175 & .325 & 3.081 \\
\hline RVista3 & -.004 & .036 & -.002 & .910 & .731 & 1.367 \\
\hline RVista4 & .041 & .038 & .026 & .281 & .261 & 3.836 \\
\hline DistMetre & .000 & .000 & .019 & .559 & .146 & 6.857 \\
\hline fWF1 & -.024 & .065 & -.007 & .714 & .394 & 2.539 \\
\hline fWF3 & -.007 & .032 & -.006 & .813 & .201 & 4.984 \\
\hline FscreenV & .100 & .046 & .051 & .033 & .266 & 3.755 \\
\hline FsideV & .160 & .040 & .096 & .000 & .262 & 3.824 \\
\hline RfacingV & -.042 & .035 & -.037 & .233 & .153 & 6.517 \\
\hline newH & -.015 & .026 & -.015 & .560 & .235 & 4.264 \\
\hline Bed3\&4 & .055 & .043 & .058 & .204 & .072 & 13.878 \\
\hline year01 & .310 & .030 & .195 & .000 & .427 & 2.342 \\
\hline year02 & .407 & .025 & .289 & .000 & .481 & 2.080 \\
\hline year03 & .683 & .024 & .374 & .000 & .850 & 1.177 \\
\hline year04 & .963 & .027 & .491 & .000 & .772 & 1.295 \\
\hline year05 & .973 & .031 & .654 & .000 & .355 & 2.814 \\
\hline year06 & 1.026 & .025 & .614 & .000 & .688 & 1.454 \\
\hline year07 & 1.026 & .038 & .376 & .000 & .777 & 1.286 \\
\hline toploction & .139 & .058 & .099 & .017 & .089 & 11.185 \\
\hline medloction & -.078 & .052 & -.070 & .135 & .068 & 14.613 \\
\hline time sold in months from $1 / 1 / 2000$ & .000 & .000 & -.015 & .315 & .643 & 1.554 \\
\hline
\end{tabular}

ingV"), was found to be significant and positive at the $5 \%$ level, but "sidrfint" which is the interaction between side and front views ("FsideV \& FfacingV") of the wind farm are negatively, marginally significant at the $10 \%$ level.

All year of sale ("year") dummies are positively significant compared to 'sales completed in the year 2000, and they show the yearly inflation of the log of house price ("Inprice"). The dummies for the postcode representing the top location (e.g. Halifax Road), significantly increases the log of house price; note that the inclusion of this variable partly controls the spatial covariance between similar house prices.
The above regression model (Table 6) can explain $97.5 \%\left(R^{2}=0.975\right.$, shown in Table 7$)$ of the variation in house price. The homogeneity test of the residuals shows that the residuals are homogenously distributed for 10 ordered categories of predicted values (hetroskedasticity test, Table 8).

The independence of the error term and the independent variables were also tested by regressing the residuals on the independent variables (Hoen, 2006). The coefficient of independent values were close to zero and were therefore not significant (f-value 0.002, p-value $\left.1.000, R^{2}=0.000\right)$. 
Table 6. Regression coefficients for model including independent variables and interactions

\begin{tabular}{|c|c|c|c|c|}
\hline \multirow[t]{2}{*}{ Model } & \multicolumn{2}{|c|}{ Unstandardized coefficients } & \multirow{2}{*}{$\frac{\text { Standardized coefficients }}{\text { Beta }}$} & \multirow[t]{2}{*}{ Sig. } \\
\hline & $\mathrm{B}$ & Std. Error & & \\
\hline (Constant) & 10.645 & .249 & & .000 \\
\hline Terrace & -.073 & .017 & -.074 & .000 \\
\hline offroad & .013 & .020 & .014 & .523 \\
\hline FVista2 & .040 & .038 & .038 & .295 \\
\hline FVista3 & -.038 & .080 & -.008 & .636 \\
\hline RVista2 & .024 & .055 & .010 & .663 \\
\hline RVista3 & -.011 & .035 & -.004 & .749 \\
\hline RVista 4 & .022 & .036 & .014 & .551 \\
\hline DistMetre & $7.426 \mathrm{E}-5$ & .000 & .012 & .707 \\
\hline fWF1 & -.026 & .061 & -.008 & .675 \\
\hline FscreenV & .100 & .041 & .051 & .016 \\
\hline FsideV & .261 & .063 & .156 & .000 \\
\hline FfacingV & .013 & .031 & .007 & .685 \\
\hline RfacingV & -.074 & .036 & -.066 & .041 \\
\hline newH & -.021 & .024 & -.020 & .394 \\
\hline Bed3 & .012 & .028 & .012 & .684 \\
\hline time sold in months from $1 / 1 / 2000$ & .000 & .000 & -.016 & .282 \\
\hline year01 & .296 & .029 & .186 & .000 \\
\hline year02 & .399 & .024 & .283 & .000 \\
\hline year03 & .682 & .024 & .373 & .000 \\
\hline year04 & .958 & .027 & .489 & .000 \\
\hline year05 & .966 & .030 & .648 & .000 \\
\hline year06 & 1.022 & .024 & .612 & .000 \\
\hline year07 & 1.025 & .037 & .376 & .000 \\
\hline toploction & .190 & .038 & .135 & .000 \\
\hline trsviewint & .086 & .037 & .042 & .021 \\
\hline sidrfint & -.113 & .070 & -.062 & .108 \\
\hline
\end{tabular}

Table 7. Model Summary

\begin{tabular}{lllll}
\hline Model & $\mathrm{R}$ & $\mathrm{R}$ Square & Adjusted R square & Std. Error of the estimate \\
\hline 1 & $.988^{\mathrm{a}}$ & .975 & .971 & .07925 \\
\hline
\end{tabular}

a. Dependent Variable: lnprice

Table 8. ANOVA for studentized residual

\begin{tabular}{lllllc}
\hline & Sum of squares & $\mathrm{df}$ & Mean square & $\mathrm{F}$ & Sig. \\
\hline Between groups & 5.100 & 9 & .567 & .539 & .845 \\
Within groups & 197.519 & 188 & 1.051 & & \\
Total & 202.618 & 197 & & & \\
\hline
\end{tabular}


Table 9 shows the result of applying a stepwise regression analysis in which all variables must pass the criterion level of 99 per cent to be entered in the equation. In addition, a variable was not included if it would cause the tolerance of another variable already in the model to drop below the tolerance criterion. Using this method to calculate the significant determinants of log of house price in St Eval suggest that, the variables representing the differences between postcodes ("toploction"), dummies for year sold ("year"), screen view ("FscreenV") and side view ("FsideV") of the wind farm from the front of the house, and the interaction between them ("FsideV" and "FscreenV") are significantly important in predicting house prices. Similar to the full regression model, these variables collectively also explain $97.2 \%\left(\mathrm{R}^{2}=0.972\right)$ of the total variation in log of house price. This indicates that, in the presence of the above important variables, the effects of other factors on house price are not that important. In other words, the effects of other variables are embedded in these factors.

\section{CONCLUSIONS AND FURTHER RESEARCH}

The aim of this research was to determine whether the presence of a wind farm influenced proximate house prices. The study focused on one location in the UK where there were a significant number of houses located within half a mile of a wind farm to enable a hedonic regression analysis to be undertaken. Whilst there was some indication that the different visual aspects enjoyed by houses in this location might influence transaction price (for example countryside, see Table 5), this was not found to be significant in the analysis (Table 8). No relationship was observed between the number of wind turbines visible and a reduction in value. Nor was there any significant evidence to suggest a relationship between distance to the wind farm and house price.

The results from the analysis suggest that the main determinants for transaction price in St Eval are, the location within the area, the year of sale, the type of the house, the orientation of the wind farm relative to the front of

Table 9. Stepwise Regression

\begin{tabular}{lllll}
\hline & \multicolumn{2}{l}{ Unstandardized coefficients } & & Standardized coefficients \\
\cline { 2 - 3 } (Constant) & $\mathrm{B}$ & Std. Error & Beta & \\
toplocation & 10.737 & .011 & & .000 \\
year06 & .174 & .026 & .124 & .000 \\
year04 & 1.026 & .023 & .614 & .000 \\
year05 & .955 & .026 & .487 & .000 \\
year07 & .963 & .028 & .647 & .000 \\
year03 & 1.048 & .034 & .384 & .000 \\
year02 & .689 & .023 & .377 & .000 \\
year01 & .401 & .022 & .284 & .000 \\
Terrace & .314 & .021 & .198 & .000 \\
FsideV & -.061 & .014 & -.061 & .000 \\
siderfint & .293 & .047 & .175 & .000 \\
FscreenV &. .202 & .051 & -.110 & .000 \\
\hline
\end{tabular}


the house and the interaction between them. The average (natural) log of house price in this area can be expressed by the equation:

$\ln ($ price $)=£ 10.737$ (Constant $)+$ toplocation $x$ $£ .174+$ year06 $x £ 1.026+$ year0 $4 x £ .955+$ year05 $x £ .963+$ year07 $x £ 1.048+$ year03 $x £ .689+$ year02 $x £ .401+$ year01 $x £ .314+$ terrace $x$ $-£ .061+$ FsideV $x £ .293+$ sidrfint $x$-£.202 + Fscreen $V x £ .072$

Whilst the conclusions drawn relate specifically to this location, where the wind turbine height is relatively small $(60 \mathrm{~m}$ compared to modern turbines with heights of $100 \mathrm{~m}$ or above), they support the findings from other studies (Hoen 2006, Poletti, 2005) which have found no apparent relationship between the presence of a wind farm and value diminution. However, whilst there seems little evidence to suggest that wind farms reduce house prices (one exception to this was observed within the case study location; a farm where the rateable value had been reduced by one rating band due to the problem of flicker from the turbine blades), these results do raise a number of questions relating to the value or perceived value of the "vista" and the possible effect of an increase in turbine height.

As the results suggest, certain vistas can inflate or diminish house price and therefore landscape may have some intrinsic value to either community or the individual which has not been captured by the variables included in this analysis. This may become more obvious as data on properties within close proximity to wind farms increases and more analysis is undertaken. Clearly there are factors that will effects the price but cannot be measured or observed. Unmeasured or unobserved variables are responsible for additional variation in the analysis. One way to tackle this problem is through a random effect modelling approach where the unmeasured or unobserved variables for each case (house price) are consider to be a realisation of a distribution. An appropri- ate mixed effects modelling approach, at least for this data, will also address the problem of spatial autocorrelation by assigning a specific area random effect to each homogenous geographical area. This type of mixed effect modelling for hedonic analysis would be of interest for further analysis.

\section{Notes}

1 Anti-windfarm campaign groups such as Dartdorset (http://www.dartdorset.org/), Countryguardian (http://www.countryguardian.net/), Turbineaction (http://www.turbineaction.co.uk/wind-turbinefacts.htm) use websites to elicit support following a planning application for a new wind farm within their local community.

2 The location of Bears Down is shown in Figures 4 and 5.

${ }^{3}$ Google Earth can be accessed at http://code.google. com/apis/earth/

4 Bears Down windfarm statistics: - Developer: National Wind Power Ltd. Number of turbines = 16. Turbine height approx 60metres. Power MW capacity of 9.6. Homes equivalent: 5368. Source http://www.yes2wind.com/ [accessed May 2008].

5 http://www.bwea.com/ref/faq.html\#big, http:// en.wikipedia.org/wiki/Wind_turbine and http:// www.yes2wind.com/14_faq.html [accessed 20 November 2007].

\section{REFERENCES}

BBC Radio 4 (2007) Costing the Earth. [Online] Broadcast Thursday 30th August 2007. Available at: www.bbc.co.uk/radio4/science/costingtheearth_20070830.shtml [accessed 30-11-2007] and www.countryguardian.net/Costing\%20 the\%20earth.htm [accessed 20 March 2008]

Bell, R. (1999) Real Estate Damages: An Analysis of Detrimental Conditions. The Appraisal Institute.

Bond, S., Mun, S. Y., Sakornvanasak, P. and McMahon, N. (2003) The Impact of Cellular Phone Base Station Towers on Property Values. Unpublished conference paper presented at the Ninth Pacific-Rim Real Estate Society Conference, Brisbane, Australia 19-22 January 2003. 
Available at: http://www.prres.net/Papers/ Bond_The_Impact_Of_Cellular_Phone_Base_ Station_Towers_On_Property_Values.pdf [accessed 22 February 2008]

Bond, S. and Hopkins, J. (2000) The impact of transmission lines of residential property values: Results of a case study in a suburb of Wellington, NZ, Pacific Rim Property Research Journal, 6(2), pp. 52-60.

BWEA (2004) The impact of wind farm developments on local residential pricing, UK. [Online] British Wind Energy Association. Report undertaken by Tom Barrow from Knight Frank. Available at: www.bwea.com [accessed 30 November 2007]

BWEA (2008) Map of wind farms in the UK. [Online] British Wind Energy Association. Available at: http://www.bwea.com/ukwed/google. asp [accessed 26 May 2008]

Chalmers, J. A. and Roehr, S. A. (1993) Issues in the valuation of contamination property, The Appraisal Journal, 7(1), pp. 28-41.

Chan, N. (2001) Stigma and its assessment methods, Pacific Rim Property Research Journal, 7(2), pp. 126-140.

Clark, R. (2004) An ill wind blowing? The Daily Telegraph, London, UK, Feb. 14, 2004, pp. 1.

Country Guardian (2007) UK Windfarm Record, August 2007, By Site. [Online] Country Guardian Wind Farm Action Group. Available at: http:// www.countryguardian.net/WindRecord_UK_ August2007.pdf [accessed 30 November 2007]

DTI (2007) Our Energy Future - Creating A Low Carbon Economy. [Online] Department of Trade and Industry (DTI), Energy White Paper. Available at: www.dti.gov.uk/energy/ whitepaper [accessed 1 May 2008]

Des Rosiers, F. (2002) Power lines, visual encumbrance and house values: A mircospatial approach to impact measurement, Journal of Real Estate Research, 23(3), pp. 275-301.

Des Rosiers, F., Theriault, M. and Kestens, Y. (2003) Modelling the Impact of Accessibility to Services on House Prices: A Comparative Analysis of Two Methodological Approaches. In Proceedings of the 10th European Real Estate Society Conference, 11-13 June 2003, Helsinki, Finland, CD-ROM.

Des Rosiers, F., Theriault, M. and Villeneuve, P. (2000) Sorting out access and neighbourhood factors in hedonic price modelling, Journal of Property Investment and Finance, 18(3), pp. 291-315.

Diggle, P. J. and Ribeiro, P. J. (2007) Model-based Geostatistics, Springer Series in Statistics.

Fischhoff, B. (1985) Managing risk perceptions, Issues in Science and Technology, 1985 Fall, pp. 83-96.

Fleming, M. C. and Nellis, J. G. (1994) The measurement of UK house prices: A review and appraisal of the principal sources, Housing Finance, No. 24.

Fletcher, M., Gallimore, P. and Managan, J. (2000) The modelling of housing sub markets, Journal of Property Investment and Finance, 18(4), pp. 373-387.

Gallimore, P. and Jayne, M. R. (1999) Public and professional perceptions of HVOTL risks: the problem of circularity, Journal of Property Research, 16(3), pp. 243-255.

Grover, D. S. (2002) Economic Impacts of Wind Power in Kittitas County. [Online] A Report for the Phoenix Economic Development Group by ECONorthwest. Available at: http://www.catenergy.com/pdf\%20files/Kittitas\%20Wind $\% 20$ final.pdf [accessed 28 March 2005]

Hoen, B. (2006) Impacts of Windmill Visibility on Property Values in Madison County, New York. Project Report Submitted to the Faculty of the Bard Center for Environmental Policy. P.O. Box 5000. Annandale on Hudson, N.Y. 125045000. April 30, 2006.

Impact Assessment Unit (2003) Public Opinion on the Impact of the Proposed Westmill Farm Wind Farm, Watchfield, Oxfordshire. Report prepared by the Impact Assessment Unit Oxford Brookes University School of Planning, 2003.

Jordal-Jorgensen, J. (1996) Social Assessment of Wind Power: Visual Effect and Noise from Windmills-Quantifying and Valuation. [Online] AKF-Institute of Local Government Studies, Denmark, April 1996. Available at: http:// www.akf/dk/eng/wind0.htm [accessed $30 \mathrm{Au}$ gust 2007]

Kauko, T. (2002) Modelling the locational determinants of house prices. Neural network and value tree approaches. Ph.D. thesis, Utrecht: Universiteit Utrecht. 
Kauko, T. (2003) Residential property value and locational externalities, Journal of Property Investment and Finance, 21(3), pp. 250-270.

Keay, M. (2005) Wind Power in the UK: Has the Sustainable Development Commission Got it Right? Oxford Energy Comment, Oxford Institute for Energy Studies, May, 2005.

McClelland, G. H., Schulze, W. D. and Hurd, B. (1990) The effect of risk beliefs on property values: A case study of a hazardous waste site, Risk Analysis, 10(4), pp. 485-497.

Milner, C. (2004) Wind farms make people sick who live up to a mile away, The Daily Telegraph, 25/01/2004.

Mundy, W. (1992) Stigma and value, The Appraisal Journal, January 1992, pp. 7-13.

Newton, M. and Harwood, O. (2005) Windfarms asset or eyesore? Country Landowner and Rural Business, November 2005. pp. 16-18.

Poletti, P. (2005) A Real Estate Study of the Proposed Forward Wind Energy Center Dodge and Fond Du Lac Counties, Wisconsin. [Online] Prepared for Invenergy Wind LLC. Poletti and Associates, Inc. May 2005. Available at: http://psc.wi.gov/apps/erf_share/view/viewdoc. aspx?docid=35184 [accessed 12 May 2005]

Priestley, T. J. and Ignelzi, P. C. (1990) A Guide to Assessing Transmission Line Impacts in Residential Communities. Washington, DC, Edison Electric Institute.

Rosen, S. (1974) Hedonic prices and implicit markets: Product differentiation in pure competition, Journal of Political Economy, 82(1), pp. 34-55.

Rossini, P., Marano, W., Kupke, V. and Burns, M. (2002) A Comparison of Models Measuring the Implicit Price Effect of Aircraft Noise. Paper presented at the $8^{\text {th }}$ Pacific Rim Real Estate Society Conference, Christchurch, New Zealand, January 2002. Available at: http:// www.unisanet.unisa.edu.au/staff/peterrossini/Documents/A\%20comparison $\% 20$ of $\% 20$ models\%20measuring\%20the $\% 20$ implicit $\% 20$ price\%20effect.pdf [accessed 27 February 2008]

RICS (2004) Impact of Wind Farms on the Value of Residential Property and Agricultural Land. Royal Institution of Chartered Surveyors (RICS), 2004.

RSPB (2005) Wind Farms. [Online] The Royal Society for the Protection of Birds (RSPB). Avail- able at: http://www.rspb.org.uk/ourwork/policy/ windfarms/index.asp [accessed 20 May 2008]

Sagrillo, M. (2003) Putting Wind Power Effects on Birds into Perspective. American Wind Energy Association (AWEA).

Scottish Executive (2003) Public Attitudes to Windfarms: A Survey of Local Residents in Scotland. [Online] Research undertaken by Simon Braunholtz Mori Scotland on behalf of the Scottish Executive. Available at: http://www.scotland. gov.uk/Publications/2003/08/18049/25579 [accessed 26 December 2007]

Sims, S. and Dent, P. (2005) High voltage overhead power lines and property values: A residential study in the UK, Urban Studies, 24(4), pp. 665-694.

Sims, S. and Dent, P. (2007) Property stigma: wind farms are just the latest fashion, Journal of Property Investment \& Finance, 25(6), pp. 626-651.

Sims, S. and Reed, R. (2005) Windfarms, Powerlines and Phone Masts: The Changing Face of Stigma. In Proceedings of the 12th Annual European Real Estate Society Conference, 15-18 June 2005, Dublin, Ireland, CD-ROM.

Slovic, P., Layman, M., Kraus, N., Flynn, J. and Chalmers, J. (1991) Perceived risk, stigma, and potential economic impacts of high level nuclear waste repository in Nevada, Risk Analysis, 1(4), pp. 683-696.

Sterzinger, G., Beck, F. and Kostiuk, D. (2003) The Effect of Wind Development on Local Property Values. Renewable Energy Policy Project (REPP). Washington. USA.

SDC (2005) Wind Power in the UK. A guide to the key issues onshore surrounding wind power development in the UK. [Online] Sustainable Development Commission (SDC). Available at: http://www.sd-commission.org.uk/publications/ downloads/Wind_Energy-NovRev2005.pdf [accessed 20 March 2008]

WWF-UK (2001) Wind farm development and nature conservation. A guidance document for nature conservation organisations and developers when consulting over wind farm proposals in England. [Online] Prepared by English Nature, RSPB, WWF and BWEA. WWF-UK Panda House. Available at http://www.bwea. com/pdf/wfd.pdf [accessed 28 February 2008]. 


\section{SANTRAUKA}

\section{VĖJO JĖGAINIŲ POVEIKIO NAMŲ KAINOMS JUNGTINĖJE KARALYSTĖJE MODELIAVIMAS}

\section{Sally SIMS, Peter DENT, G. Reza OSKROCHI}

Šiame darbe aptariami JK atlikto tyrimo rezultatai, kuriuo, taikant hedonistinį kainu modelį, siekta nustatyti galimą vejjo jẻgainiu poveiki namų kainoms. Vyriausybès parama vejjo energijai paskatino naujo elemento, vejjo jègainès, atsiradimą aplinkoje; susirūpinta, ar vejjo jejgainių vaizdas ir garsas galètų neigiamai paveikti namų kainas. Šiame darbe nagrinejjamas 201 prekybinis sandoris, susijęs su namais, pusę mylios nutolusiais nuo Bears Down, Kornvalyje (JK), esančio 16 vejjo jègainių ūkio. Nors priežastinis ryšys tarp vejjo jëgainių ir namų kainos nepastebètas, yra įrodymų, kad jègainès keliamas triukšmas ir menčiu mirgẻjimas kai kuriems nekilnojamojo turto objektams galètų pakenkti ir kad gyventojui patikęs kaimo vaizdas gali tapti nebepatrauklus. 